OSOBA I SAMOTNOŚĆ. MIĘDZY CODZIENNOŚCIA A MISTYKA

Filozofia ChrześCijańsKa • TOM 12, Poznań 2015

Uniwersytet im. Adama Mickiewicza w Poznaniu • Wydziat Teologiczny

doi: $10.14746 /$ fc.2015.12.11

MACIEJ KOPYCIŃSKI

\title{
Jednostka a wspólnota w filozofii Charles'a Taylora
}

Individual and Community in the Philosophy of Charles Taylor

W niniejszym tekście chcę przedstawić zagadnienie relacji jednostki do wspólnoty w filozofii Charles'a Taylora. Tytułową relację odnaleźć możemy, moim zdaniem, co najmniej na dwóch płaszczyznach twórczości kanadyjskiego filozofa. Pierwszą z nich jest filozofia polityki, drugą zaś założenia antropologiczne i ich relacja do języka ${ }^{1}$.

Zacznijmy zatem od pierwszej z wymienionych płaszczyzn. Problematykę relacji jednostki do wspólnoty znajdujemy w słynnym już sporze między liberalizmem a komunitaryzmem, chociaż nie jest to jedyna oś tego wielowątkowego sporu. Sztandarowym dziełem w obozie liberalnym jest Teoria sprawiedliwości Johna Rawlsa z roku 1971, w której autor poszukuje podstaw dla bezstronnych zasad sprawiedliwości, wprowadzając figury „sytuacji pierwotnej” i „zasłony niewiedzy".

Rawlsowi idzie zatem o to - pisze w swoim komentarzu Andrzej Szahaj - że zasady sprawiedliwości, które mają określić prawa i obowiązki oraz regulować dystrybucję społecznych i ekonomicznych korzyści, powinny być pojmowane jako hipotetyczny kontrakt czy ugoda, która powstałaby wśród ludzi abstrahujących od poszczególnych aspektów ich własnych przekonań, w tym od ich własnych koncepcji „dobrego życia”2.

Kwestią zasadniczą jest tu zatem stworzenie warunków dla swobodnego określania tego, jaki kształt ma przyjąć konkretne dobro, zaś kwestia deliberacji na temat owego dobra pozostaje drugorzędna. Sprowadzając całą tę kwestię do

${ }^{1} \mathrm{~W}$ kwestii polityki poglądy Tylora są znane i szeroko komentowane, pozwolę więc sobie tylko na ich krótkie przypomnienie. O wiele bardziej interesować mnie tu będzie druga $\mathrm{z}$ wymienionych płaszczyzn problemowych.

${ }^{2}$ A. Szahaj, Jednostka czy wspólnota? Spór komunitarystów z liberałami a 'sprawa polska', Warszawa 2003, s. 13. 
jednego kluczowego sformułowania, powiedzieć można: słuszność jest pierwotna względem dobra. Ogólna zasada sprawiedliwości wyznacza w tym ujęciu ramy różnym, niekoniecznie współmiernym, koncepcjom dobra, jak również możliwości ich realizacji, które pozostają w jednostkowej władzy uznania. Co więcej, słuszność nie musi być pojmowana jako maksymalizacja dobra. Jak pisze Nancy Davis o stanowisku deontologicznym, do którego zaliczyć można teorię Rawlsa: „W rzeczy samej [deontologowie] sądzą, że nie zachodzi żaden wyraźnie określony stosunek między czynieniem tego, co słuszne, a czynieniem tego, co dobre (w sensie konsekwencjalistycznym, tj. wytwarzanie dobrego skutku)"3. W podejściu tym słuszne działanie opiera się na tzw. rygorach deontologicznych, czyli na regułach, zakazach, ograniczeniach, przy czym nie wchodzi tu $\mathrm{w}$ grę maksymalizacja ani porównywanie poszczególnych dóbr, zaś oparcia dla poszczególnych rygorów szuka się bądź to w potocznych intuicjach moralnych, bądź wyprowadza się je z jednej fundamentalnej zasady, np.: z Kantowskiego imperatywu kategorycznego czy też ze wspomnianej Rawlsowskiej zasady „sprawiedliwości jako bezstronności”.

Pierwszym dobrze wyartykułowanym dziełem, będącym zarazem początkiem całej serii komunitarystycznych krytyk, jest książka Liberalism and the Limits of Justice Michaela Sandela. Podobnie jak wiele późniejszych polemicznych pism komunitarystów (albo autorów zaliczanych do tego nurtu), krytyka ta skupia się na wizji człowieka leżącej u podstaw Rawlsowskiej koncepcji, mianowicie chodzi tu o tzw. ,suwerenny podmiot wyboru”, któremu Sandel przeciwstawia ,podmiot radykalnie usytuowany". Ujmując rzecz w wielkim skrócie: chodzi o to, że podmiot konstytuowany jest poprzez wyznawane wartości i cele, te z kolei sa wcielone w daną wspólnotę. Tożsamość jednostki jest w tym ujęciu społecznie usytuowana, uwikłana czy też „obciążona wierzytelnościami”. Role i związane z nimi obowiązki, w które zostaliśmy „rzuceni”, obligują nas do ich spełnienia. Nasze ukonstytuowanie w danej wspólnocie nie podlega naszemu wyborowi, dlatego też określone cele i wartości zastajemy jako dane, wyprzedzające niejako nasze poczucie tożsamości.

$\mathrm{Z}$ analiz Rawlsa wyłania się jednostka suwerenna, samodzielnie dokonująca wyboru dóbr i celów. „Taka jednostka - pisze Aneta Gawkowska - wyposażona jest jedynie w pewne prawa i pragnienia dóbr pierwotnych. Wszelkie inne cele mają być zdeterminowane przez nią samą, według jej życzeń i w trakcie jej życia"4. Rola wspólnoty w tej teorii sprowadza się jedynie do dostarczania neutralnych ram sprawiedliwości - praw gwarantujących bezstronne zasady. Neutral-

${ }^{3}$ N.A. Davies, Deontologia współczesna, w: Przewodnik po etyce, red. Peter Singer, Warszawa 1998 , s. 248.

${ }^{4}$ A. Gawkowska, Biorac wspólnote poważnie. Komunitarystyczne krytyki liberalizmu, Warszawa 2004, s. 79. 
ność jest tu pojmowana jako neutralność wobec jakiejkolwiek wizji dobra, zgodnie ze wspomnianą już wyżej zasadą prymatu słuszności nad dobrem5. Sandel zaś i inni komunitaryści będą w duchu Arystotelesa wskazywać na pierwszorzędną rolę dobra jako celu oraz niezbywalną rolę wspólnoty w realizowaniu określonych dóbr, a więc w sferze politycznej, pojmowanej tu jako przedłużenie moralności'.

Jak sytuuje się w kontekście tej debaty Taylor? Jakkolwiek sam kanadyjski myśliciel wzbrania się przed określeniem komunitarysta, to rozstrzygnięcia filozoficzne, jakie znajdujemy w jego pismach, lokują go zdecydowanie bardziej w „drużynie K”, niż w „drużynie L" .

Zdaniem Taylora, pomimo faktycznych różnic dzielących oba obozy, wiele spornych kwestii wynika po prostu z pomieszania pojęć, dlatego warto wyróżnić tu dwie płaszczyzny: pierwsza dotyczy kwestii ontologicznych, druga zaś kwestii preferencji. Poziom ontologiczny dotyczy ostatecznych kategorii w procesie wyjaśniania zjawisk społecznych. Tu możemy wyróżnić atomistów (metodologiczny indywidualizm - ostatecznymi kryteriami będą tu własności działających jednostek, zaś dobro społeczne sprowadza się do sumy dóbr indywidualnych) i holistów ${ }^{8}$. Natomiast płaszczyzna preferencji jest związana z postawą moralną i linią postępowania. „Innymi słowy, są to różnorakie próby odpowiedzi na pytanie o pożądany kształt instytucji społecznych i politycznych oraz o właściwy lub słuszny zbiór wartości moralnych, którym winny być podporządkowane"".

Taylor konstatuje złożoność relacji między tymi płaszczyznami - nie zachodzi tu relacja prostej determinacji, a jednak ,nie są one od siebie zupełnie niezależne, ponieważ stanowisko, jakie zajmujesz na poziomie ontologicznym, może należeć do istotnych fundamentów twoich preferencji”' ${ }^{10}$. Znaczna część nieporozumienia w debacie liberalno-komunitarystycznej wiąże się właśnie z pomieszaniem tych poziomów ${ }^{11}$.

\footnotetext{
${ }^{5}$ Świadomie pomijam tu kolejne konsekwencje tych założeń.

${ }^{6} \mathrm{Na}$ omawiany tu spór można spojrzeć również z perspektywy sporu o wartości: jako spór między wolnością, równością i braterstwem. Na ten temat zob. R. Prostak, Rzecz o sprawiedliwości. Komunitarystyczna krytyka wspótczesnego liberalizmu amerykańskiego, Kraków 2004; W. Kymlicka, Braterstwo, w: Przewodnik po wspótczesnej filozofii politycznej, red. R.E. Goodin i P. Pettit, thum. C. Cieślak, M. Poręba, Warszawa 1998.

${ }^{7}$ Jest to określenie samego Taylora, który tak właśnie określa komunitarystów (Michael Sandel, Alasdair MacIntyre, Michael Walzer) zaś filozofów liberalnych - „drużyną L” (John Rawls, Ronald Dworkin, Thomas Nagel).

${ }^{8}$ Ch. Taylor, Nieporozumienia wokót debaty liberalno-komunitariańskiej, w: Komunitarianie. Wybór tekstów, red. P. Śpiewak, tłum. P. Rymarczyk, T. Szubka, Warszawa 2004, s. 37-38.

${ }^{9}$ D. Drałus, Charles Taylor. Sprzeczności między filozofia praktyczna a praktyka filozoficzna, w: Indywidualizm, wspólnotowość, polityka, red. M.N. Jakubowski, A. Szahaj, K. Abriszewski, Torun 2002, s. 230.

${ }^{10}$ Ch. Taylor, Nieporozumienia..., dz. cyt., s. 39.

${ }^{11}$ Dokładniej mówiąc, krytyczne odniesienie do Sandelowskiej tezy o ,podmiocie usytuowa-
} 
Porządne rozeznanie poziomu ontologicznego ma na celu dokładne uporządkowanie pola możliwości. Jednak dokonując samego wyboru, nie możemy obejść się bez tez normatywnych.

Znaczenie powyższej tezy uwidacznia się, gdy przyjrzymy się jeszcze jednemu punktowi sporu Sandela z Rawlsem - chodzi tu o zasadę dyferencji, wspierającą Rawlsowski egalitaryzm. Zasada ta mówi o posiadanych przez jednostki zasobach jako o należących do wspólnego dobra społecznego, poddających się odpowiedniej dyspozycji. Jednak takie ujęcie nolens volens zakłada dosyć duży poziom społecznej solidarności, ta zaś opierać się może tylko na ,jaźni zakorzenionej”, o silnych uczuciach wspólnotowych. Niestety, teoria Rawsla przyjmuje, że uczestnicy relacji społecznych są sobie obojętni. „W tym wypadku znowu jasne jest - twierdzi Taylor - że celem wywodów Sandela - słusznych czy nie jest określenie alternatyw w sytuacji rzeczywistego wyboru" ${ }^{2}$. Zatem nieuchronnie wyłania się kwestia możliwości egalitarnej redystrybucji (poziom preferencji), jeżeli na poziomie ontologicznym założyliśmy atomizm. Z kolei po przyjęciu ontologicznego holizmu, czyli „mocnej wspólnoty”, powstaje pytanie o możliwości jej oparcia w głównej mierze na zasadzie sprawiedliwości. Innymi słowy, należy zapytać, czy w grę nie wchodzą tu inne dobra? „Twierdzę - pisze Taylor - że to właśnie tego rodzaju pokazywanie możliwych wyborów stanowi główną funkcję tego, co nazwałem twierdzeniami ontologicznymi. To w ten sposób Sandelowska krytyka powinna być odczytywana - nie jako opowiedzenie się za konkurencyjnymi preferencjami"'13.

Zdaniem Taylora, właśnie z powodu umieszczania owych dwóch poziomów same terminy „liberalizm” i „komunitaryzm” powinny zostać odrzucone, albowiem sugerują one, że spór toczy się tylko i wyłącznie na poziomie preferencji. Innymi słowy: „drużyna L” stawia bardziej na wartość wolności, „drużyna K” na wartość braterstwa. Jeżeli już zauważone zostają rozstrzygnięcia na poziomie ontologicznym, sądzi się co najwyżej, że są pochodną rozstrzygnięć z poziomu preferencji. „Dowolne stanowisko - twierdzi Taylor - w sporze między atomizmem i holizmem może iść $\mathrm{w}$ parze $\mathrm{z}$ dowolnym stanowiskiem między indywidualizmem i kolektywizmem"14. W filozofii wykrystalizowały się już stanowiska takie jak indywidualistyczny atomizm, prezentowany przez Roberta Nozika, holistyczny kolektywizm w wydaniu Karola Marksa, dalej: holistyczny indywidualizm (Wilhelm von Humboldt) oraz nieco kuriozalny atomistyczny kolektywizm w wydaniu Burrhusa F. Skinnera. Jak nietrudno się domyślić, sam autor Źródet podmiotowości opowiada się za opcją wyznaczoną przez Humboldta, al-

nym" zasadzało się na jej interpretacji jako twierdzenia dotyczącego poziomu preferencji. Wedle Taylora, Liberalism and the Limits of Justice jest rozprawą z zakresu społecznej ontologii.

${ }^{12}$ Ch. Taylor, Nieporozumienia..., dz. cyt., s. 42.

${ }^{13}$ Tamże.

${ }^{14}$ Tamże, s. 43. 
bowiem filozofowie zajmujący stanowisko holistycznego indywidualizmu ,reprezentują [...] trend myślowy, który jest w pełni świadom (ontologicznych) społecznych uwarunkowań ludzkich podmiotów, ale bardzo wysoko ceni wolność i indywidualną odmienność. [...] W świetle tych faktów jest zdumiewające, że ktokolwiek może uważać, iż obrona holizmu pociąga za sobą opowiedzenie się za kolektywizmem"15.

A zatem jak wygląda interesujący nas tu związek takiego postrzegania jednostki i wspólnoty? Sam Taylor określa to w taki oto sposób:

Społeczny pogląd na człowieka to pogląd, wedle którego esencjalny warunek konstytucyjny poszukiwania dobra przez człowieka jest związany z byciem w społeczeństwie. A zatem twierdzę, że człowiek nie może być podmiotem moralnym, a więc i kandydatem do ludzkiego dobra, poza wspólnotą jakiegoś języka i związanego $\mathrm{z}$ wzajemnością dyskursu o tym, co dobre i co złe, sprawiedliwe i niesprawiedliwe. Odrzucam wszystkie atomistyczne poglądy, albowiem to, co człowiek bierze ze społeczeństwa, to nie jakaś pomoc w realizacji dobra, lecz sama możliwość bycia podmiotem poszukującym tegoż dobra ${ }^{16}$.

Pomijając kwestię języka, po prostu nie sposób zrozumieć takiego stanowiska, jakim jest holistyczny indywidualizm. W tym miejscu przechodzimy do drugiej płaszczyzny problemowej, a w zasadzie tylko innego aspektu relacji jednostka a wspólnota.

Od strony języka chciałbym umieścić stanowisko Taylora pomiędzy dwoma paradygmatami, jakie wskazała Agata Bielik-Robson w swojej pracy: Na drugim brzegu nihilizmu. Filozofia w poszukiwaniu nowego podmiotu ${ }^{17}$.

Za wyraźnym rozdzieleniem owych paradygmatów przemawiają fundamentalne różnice właśnie w pojmowaniu języka i jednostki ludzkiej, różnice, które dzielą niemal całą współczesną filozofię, doprowadzając do swoistej „wojny o podmiot”. Ogólnie rzecz biorąc, Bielik-Robson zastanawia się nad koncepcjami podmiotowości, jakie zrodziła XX-wieczna filozofia ${ }^{18}$. Owe dwa stanowiska to z jednej strony podejście obiektywistyczne, redukujące podmiotowość do jej ogólnych uwarunkowań. Podmiot w tym ujęciu staje się tylko epifenomenem

15 Tamże.

${ }^{16}$ Ch. Taylor, The Nature and the Scope of Distributive Justice, w: tenże, Philosophy and the Human Science. Philosophical Papers, Cambridge 1985, s. 292, cyt. za: A. Szahaj, Jednostka czy wspólnota?, dz. cyt., s. 18.

${ }^{17}$ A. Bielik-Robson, Na drugim brzegu nihilizmu. Filozofia współczesna w poszukiwaniu nowego podmiotu, Warszawa 1997.

18 Projekt Bielik-Robson sięga o wiele dalej niż prosta konstatacja różnic między przywołanymi tu opcjami filozoficznymi i polega na pokazaniu potencjalnych podobieństw między strukturalizmem, hermeneutyką i psychoanalizą, ryzykując jednocześnie podtrzymanie niewspółmiernych języków tychże koncepcji. Pomijając, skądinąd ciekawe wyniki tej pracy, w dalszej części sięgniemy tylko do uwag poświęconych Taylorowi. 
głębszej (czy raczej należałoby dodać: zewnętrznej) rzeczywistości. Z drugiej strony mamy subiektywizm głoszący podmiotową niezależność od wszelkich determinacji niepodmiotowych ${ }^{19}$. Jednym $\mathrm{z}$ głównych zamiarów autorki jest pokazanie stanowiska, które przekraczałoby ów dualizm, innymi słowy, pokazanie, jak możliwa jest wolność i autonomia podmiotu uwarunkowanego, ale niezredukowanego do owych uwarunkowań.

Powyżej zarysowanej opozycji z grubsza odpowiadają dwa filozoficzne paradygmaty: strukturalizm byłby tu stanowiskiem obiektywistyczym, zaś filozofia świadomości - subiektywistycznym. Bielik-Robson twierdzi, że strukturalizm rozwija podstawowy „dogmat obiektywizmu”, którym jest „teza o wtórności świadomości wobec języka. Słowami Derridy: «Mowa wyprzedza moją świadomość samego siebie»" ${ }^{20}$. To właśnie w tym nurcie pojawiają się znamienne twierdzenia, począwszy od Lévi-Straussa, o tym, że mówią mity, nie zaś sam człowiek, poprzez śmierć autora (Roland Barthes) do tezy o śmierci podmiotu (Foucault). Z kolei szczytowym osiagnięciem subiektywistycznej filozofii świadomości byłby transcendentalizm Husserla z jego ,ja transcendentalnym” będącym ostatecznym warunkiem konstytucji sensu, sam nie będąc już niczym uwarunkowany.

Między tymi skrajnościami istnieje jeszcze trzecie stanowisko inaczej rozwiązujące kwestię uwarunkowań. Chodzi tu głównie o filozofię hermeneutyczną.

Hermeneutyka wskazuje na mechanizmy, dzięki którym wzbogaca się i rozwija język podmiotowej refleksji w konfrontacji z dziedzictwem kulturowym. Dowodzi tym samym, że jednostka, której strukturalizm przyznaje status mniej lub bardziej biernego użytkownika reguł, awansuje do roli ich współtwórcy. Zamieniając słowo „determinacja” na „konfrontacja” oraz „dialog”, hermeneutyka podkreśla niezbywalną twórczą rolę jednostki w procesie reprodukcji kultury ${ }^{21}$.

W tym właśnie kontekście pojawia się Charles Taylor i jego wersja autointerpretacji, będąca inspiracją do podjęcia problemu nadawania sensu własnym uwarunkowaniom i granicy swobody interpretacyjnej.

Dla hermeneutycznego pojmowania podmiotowości kluczowa była tzw. „ontologizacja rozumienia”, dokonana przez Martina Heideggera. W haśle tym zawiera się przejście od pojmowania podmiotu, dla którego tożsamości fundamen-

${ }^{19}$ A. Bielik-Robson, Na drugim brzegu nihilizmu, dz. cyt., s. 129.

${ }^{20}$ Tamże, s. 130. W innej książce Bielik-Robson, podejmując ten sam problem, tym razem poprzez pojęcie „wpływu”, o dekonstrukcji pisze następująco: „Dekonstrukcyjna skepsis skutecznie podważa filozoficzne fundamenty subiektywności, wiodąc do załamania wiary w autonomię podmiotową, w końcu zaś do hasła ostatecznej «śmierci podmiotu». [...] Dekonstrukcjoniści zajmują się więc procesem wywłaszczania podmiotowości, która bezpowrotnie traci suwerenność na rzecz tego, co ma na nią największy wpływ i ją formuje: przede wszystkim języka" - A. Bielik-Robson, Duch powierzchni. Rewizja romantyczna i filozofia, Kraków 2004, s. 42-43.

${ }^{21}$ A. Bielik-Robson, Na drugim brzegu nihilizmu, dz. cyt., s. 132. 
talna jest relacja samoświadomości, do podmiotu jako bycia-w-świecie, gdzie świadomość, jak i samoświadomość, jest wtórna wobec praktyk życiowych, nie redukując jej wszakże jedynie do epifenomenu społecznych czy językowych struktur. Zmiany tej nie musimy wcale postrzegać jako radykalnego zerwania. W swojej monografii o hermeneutyce ${ }^{22}$ Andrzej Przyłębski wskazuje raczej na istotne przeformułowanie modelu samoodniesienia. Wyjściowy punkt nowożytnej filozofii, czyli „fakt świadomości”, od którego zaczynano badania fundamentów i prawomocności wiedzy, zostaje fundamentalnie przeinterpretowany, stając się inną już konstelacją. „Znika filozoficzny fundamentalizm, zmienia się ujęcie poznania oraz prawdy, które myślane są z perspektywy ludzkiej kultury i społecznej praxis. To samo dotyczy kwestii wolności i odniesienia do wartości. Zmienia się oczywiście także podejście do badań etycznych, estetycznych, a także logicznych"23.

Język jest postrzegany przez Taylora przede wszystkim jako medium, lecz nie jest to medium neutralne. Przykładowo w procesach artykulacji naszych uczuć język nie tylko pośredniczy w ich ekspresji, lecz także kształtuje, a fakt, że jako ludzie jesteśmy istotami językowymi, sprawia, iż nawet to, co jeszcze niepoddane interpretującemu artykułowaniu, zawsze staje pod znakiem zapytania, domagając się rozjaśnienia.

Samorozumienie nie odbywa się w przestrzeni zupełnej dowolności, albowiem właśnie poprzez swój językowy charakter wiąże się ze wspólnotą. „Język istnieje i jest podtrzymywany jedynie w obrębie pewnej wspólnoty języka. [...] Podmiotem można być tylko pośród innych podmiotów. Podmiotu nie sposób opisać bez odwołania do innych podmiotów"24.

Kiedy pytamy kogoś „Kim jesteś?”, a więc o jego tożsamość, odpowiedź z konieczności jest określeniem miejsca tego, kto udziela odpowiedzi. Jest to określenie swego miejsca $\mathrm{w}$ przestrzeni społecznej i prywatnej, określenie hierarchii ważności związków i powiązań z innymi ludźmi.

Bez wprowadzenia w język, w kulturę jako nieustanną konwersację, nie moglibyśmy stać się w pełni osobami. Rozmowa umożliwia wspólnotę, w sensie ustanawiania wspólnej przestrzeni jako możliwości działania i porozumiewania.

Dzięki takiej przestrzeni uczymy się tego, czym jest gniew, miłość itp., ale jest to możliwe dlatego właśnie, że doświadczamy tych zjawisk jako przedmiotów dla nas, w pewnej wspólnej przestrzeni ${ }^{25}$. Wszelkie zmiany $i$ indywidualizacja rozumienia zasadzają się na uprzedniości wspólnego języka. Dialogiczność

\footnotetext{
${ }^{22}$ A. Przyłębski, Hermeneutyczny zwrot filozofii, Poznań 2005.

${ }^{23}$ Tamże, s. 26.

${ }^{24}$ Ch. Taylor, Źródła podmiotowości. Narodziny tożsamości nowoczesnej, thum. M. Gruszczyński, O. Latek i in., Warszawa 2001, s. 68.

${ }^{25}$ Tak można rozumieć słynne twierdzenie Wittgensteina, że zgoda, co do znaczeń, zakłada zgodę co do sądów.
} 
jest, wedle Taylora, powszechną cechą ludzkiej egzystencji. „Stajemy się w pełni podmiotami - zdolnymi rozumieć siebie i dzięki temu określić swoją tożsamość - w wyniku przyswojenia bogatych języków ekspresji człowieka. [...] Uczymy się ich w procesie komunikacji z innymi ludźmi. Nikt nie przyswaja sobie języka umożliwiającego mu samookreślanie samodzielnie"26.

Język zatem jest tu rozumiany w szerokim sensie, również jako język sztuki, gestów, innymi słowy, jako symboliczne formy ekspresji oraz wspólny sposób reprezentacji i opisu świata ${ }^{27}$. Stąd też dialog ma bardzo szerokie znaczenie. Nie chodzi tu tylko o opis tego, jak wrastamy w język w procesie socjalizacji. Taylor mówi, że chodzi mu wręcz o odsłonięcie „transcendentalnego" warunku panowania nad własnym językiem. Oznacza to, że dialogiczny sposób bycia charakteryzuje całość życia. Dialog jest ciagłym odniesieniem do autorytetów, do „znaczących innych", nawet gdy są już bezpośrednio nieobecni. Dialog nie musi mieć „empirycznego" charakteru, w sensie realnego społecznego działania, może on odnosić się do „wspólnoty wyobrażonej”, przybierając postać „duchowej konwersacji”: „Możemy drastycznie zmienić układ sił w naszej definicji tożsamości, zdetronizować daną, historyczną wspólnotę pełniącą do tej pory rolę osi tożsamości i odnieść się jedynie do wspólnoty określonej przez wyznawane dobro (zbawionych, wiernych lub mądrych). To jednak nie unieważnia naszej zależności od sieci konwersacji” ${ }^{28}$. Odniesienie takie może przybierać formy potwierdzania, uzgadniania, jak również konfrontacji.

Tak pokrótce rysuje się problematyka relacji jednostki i wspólnoty w filozofii Charles'a Taylora. Należy podkreślić, że powyższe rozważania mają charakter analityczny, zaś twórczość Taylora obfituje również w interpretacje historyczno-antropologiczne dotyczace m.in. omawianego tutaj zagadnienia, czego najlepszy przykład stanowią Źródła podmiotowości. Schemat analityczny, który zaprezentował Taylor, wraz z jego dookreśleniem roli języka oraz roli „wspólnot wyobrażonych", naszym zdaniem, stanowi dogodny punkt wyjścia przydatny do analiz innych stanowisk teoretycznych, ale też do podjęcia przemyślenia wielu typowo współczesnych zjawisk i problemów wyłaniających się wraz z ewolucją współczesnej cywilizacji. Przykładem takiego zjawiska może być choćby samotność. Wydaje się, że na gruncie rozważań Taylora samotność radykalna, rozumiana jako stan zupełnego odcięcia od wspólnoty, byłaby stanem nie tyle niepożądanym, ile wręcz niemożliwym. Podmiot, który nie pozostaje w relacji do innych, chociażby relacji jedynie wyobrażonej, zapośredniczonej przez medium języka czy nawet wspomnień, nie byłby w ogóle podmiotem. Możemy jedynie domniemywać, co oznaczałby dla człowieka zupełny brak odniesienia do innych. Z pew-

\footnotetext{
${ }^{26}$ Ch. Taylor, Etyka Autentyczności, tłum. A. Pawelec, Kraków 1996, s. 32.

${ }^{27}$ A. Gawkowska, Biorq̨ wspólnotę poważnie, dz. cyt., s. 100.

${ }^{28}$ Ch. Taylor, Źródła podmiotowości, dz. cyt., s. 78
} 
nością pociagałoby to rezygnację z języka, który jest przecież tworem wspólnotowym. Taylor zgadza się $\mathrm{z}$ tezą Wittgensteina o niemożliwości istnienia języka prywatnego, stąd też radykalna samotność oznaczałaby również zupełne zerwanie komunikacji. A zatem pytanie, czym lub kim miałby być taki podmiot, pozostaje dla nas zamknięte. $Z$ pewnością byłby czymś bardzo nieludzkim.

Natomiast na gruncie rozważań Taylora możemy wyobrazić sobie różne formy samotności, np. samotność przejściową czy też samotność jedynie częściową, np. oddalenie przestrzenne. Jednak możliwość zaistnienia takich stanów nie unieważnia podstawowego twierdzenia Taylora, że podmiot ma charakter fundametalnie dialogiczny. Stąd też duży nacisk Taylora na język i czasowy wymiar naszej egzystencji, dzięki któremu to, co wspólnotowe, może zakorzenić się $\mathrm{w}$ nas i trwa nawet $\mathrm{w}$ stanie oddzielenia $\mathrm{w}$ postaci wspomnień, wyobrażeń czy właśnie języka, który otwiera i zapośrednicza nam świat. Choć nie sposób nie zgodzić się z Taylorem, to warto zauważyć, że położenie nacisku na język przysłoniło jednak cielesny wymiar ludzkiej egzystencji i refleksję nad bezpośrednim współbyciem z innymi. Nałożenie tego wymiaru może dać nieco bogatszy schemat analityczny, za pomocą którego rozpatrywać będziemy takie zagadnienia jak samotność. Z tak rozszerzonym zestawem pojęć zjawisko samotności okazuje się jeszcze bardziej złożone, ale też zarazem intelektualnie intrygujące.

\section{BIBLIOGRAFIA}

Bielik-Robson A., Na drugim brzegu nihilizmu. Filozofia współczesna w poszukiwaniu nowego podmiotu, IFiS PAN, Warszawa 1997.

Bielik-Robson A., Duch powierzchni. Rewizja romantyczna i filozofia, Univeristas, Kraków 2004.

Davies N.A., Deontologia wspótczesna, w: Przewodnik po etyce, red. P. Singer, Książka i Wiedza, Warszawa 1998.

Gawkowska A., Biorqc wspólnotę poważnie. Komunitarystyczne krytyki liberalizmu, IFiS PAN, Warszawa 2004.

Kymlicka W., Braterstwo, w: Przewodnik po wspótczesnej filozofii politycznej, red. R.E. Goodin i P. Pettit, tłum. C. Cieślak, M. Poręba, Książka i Wiedza, Warszawa 1998.

Prostak R., Rzecz o sprawiedliwości. Komunitarystyczna krytyka wspótczesnego liberalizmu amerykańskiego, Wydawnictwo Uniwersytetu Jagiellońskiego, Kraków 2004.

Przyłębski A., Hermeneutyczny zwrot filozofii, UAM, Poznań 2005.

Szahaj A., Jednostka czy wspólnota? Spór komunitarystów z liberałami a 'sprawa polska', Aletheia, Warszawa 2003.

Taylor Ch., Nieporozumienia wokót debaty liberalno-komunitariańskiej, w: Komunitanianie. Wybór tekstów, red. P. Śpiewak, tłum. P. Rymarczyk, T. Szubka, Aletheia, Warszawa 2004 , s. 37-38. 
Taylor Ch., Etyka Autentyczności, tłum. A. Pawelec, Znak, Kraków 1996.

Taylor Ch., Źródła podmiotowości. Narodziny tożsamości nowoczesnej, thum. M. Gruszczyński, O. Latek i in., PWN, Warszawa 2001.

\section{SUMMARY}

In my article I analyse relation of individual and community in Charles Taylor's philosophy. This relation is presented on two problematic levels. On the first level he concentrates on political philosophy and the second one relates to subject and language. In his political philosophy Charles Taylor starts from liberal - communitarian debate which is a basis for his own position, so-called holistic individualism. It means that on the ontological level individual is unavoidable involved in bonds of community but on the level of preferences individualism is highly valued. On the second level Taylor tries to break extremes of structuralism and idealism. In this case he refers to hermeneutic philosophy and shows the subject as a dialogical one and as a co-author of rules which determine himself.

Translated by Agata Miętek

\section{Keywords}

individual, community, liberalism, hermeneutic, dialogue, self-understanding

\section{Słowa kluczowe}

jednostka, wspólnota, komunitaryzm, liberalizm, hermeneutyka, dialog, samorozumienie 